\title{
On the Use of Cognitive Verbs in Political Interviews
}

\begin{abstract}
This paper focuses on the use and functions of cognitive verbs in the genre of political interview. These verbs are frequently used in argumentative discourse to modify the meaning conveyed in a proposition and to show different degrees of speaker involvement. Apart from expressing a subjective standpoint, they also have an intersubjective function, which means that they show the recipient how the speaker's viewpoint expressed in the proposition should be understood. The intersubjective perspective also indicates that a certain piece of information conveyed by the speaker is open for negotiation. The aim of this contribution is to examine the distribution, frequency and functions of cognitive verbs occurring in a corpus of political interviews and to find out how these constructions modify the meaning of utterances. Since these verbs co-occur frequently with discourse markers such as and, because, but, so, well, etc., these configurations were investigated as well.
\end{abstract}

\section{Key words}

Cognitive verbs; parentheticals; political interview; pragmatic functions; intersubjectivity

\section{Introduction}

In the majority of communicative exchanges, be they spoken or written, participants not only exchange factual information, but also information about the nature of their interpersonal relationship and social status, about the degree of involvement towards the validity of their contribution, about how they intend their statements to be understood by the audience. It is at the interface between 
propositional and non-propositional information where cognitive verbs are important, especially when used as parentheticals.

This contribution focuses on the use and functions of cognitive verbs in political interviews. Cognitive verbs in the first person present tense are frequently used in this type of argumentative discourse to modify the propositional meaning and thus show different degrees of speaker involvement. Depending on the context and prosodic patterns, they may intensify or attenuate the illocutionary force of propositions. Apart from expressing subjectivity, cognitive verbs also have an intersubjective function, which means that they show the recipient how to structure and understand the speaker's viewpoint expressed in the proposition. When using this type of verbs, politicians may open up dialogic space for further negotiation and alternative positions.

The aim of this paper is to examine the distribution, frequency and functions of cognitive verbs occurring in a corpus of political interviews and to find out how they modify the meaning of utterances. The focus is on the most frequent cognitive verbs appearing in the corpus, namely I think, I mean, and I believe. They may co-occur with discourse markers such as and, because, but, so, and well, therefore these configurations were investigated as well.

The structure of this paper is as follows: Section 2 describes various approaches of several scholars to cognitive verbs and common terminology, Section 3 explains the use of cognitive verbs as so called parentheticals. Material under investigation and methodology adopted in this study are briefly described in Section 4. Results of quantitative analysis are introduced in Section 5. The following chapter discusses pragmatic functions of cognitive verbs examined in the corpus. Collocations of cognitive verbs with discourse markers are analysed in Section 7 and, finally, the closing chapter summarises the results of this study.

\section{Cognitive verbs}

Cognitive verbs have attracted much attention in English linguistics and have been described and researched by many scholars. They are classified, for instance, as private verbs by Biber (1988), who considers them as one subgroup of specialized verb classes. Private verbs express intellectual states and refer to mental activities (e.g. assume, believe, guess, mean, suppose, think, decide, demonstrate, discover, doubt, find, feel, know, learn, realize, etc.).

Quirk et al. (1985) regard public and private verbs as subgroups of factual verbs. Factual verbs introduce "factual or propositional information" (Quirk et al. 1985: 1180). Private verbs express "intellectual states such as belief and intellectual acts such as discovery" (Quirk et al. 1985: 1181). These verbs are called private because they express states and acts which cannot be observed. As Quirk et al. put it: "a person may be observed to assert that God exists, but not to believe that God exists. Belief is in this sense "private" (1985: 1181, italics in original). 
These private states "can only be subjectively verified: $i e$ states of mind, volition, attitude, etc." (1985: 202, italics in original).

Private verbs have also been dealt with Palmer (1987), who describes these verbs as those referring to "states or activities that the speaker alone is aware of" (1987: 72). The first group of these verbs denotes mental activities (e.g. think, believe, hope, imagine), the latter denotes sensations (see, smell, hear, taste, feel). Both categories usually appear in non-progressive forms.

Verb classes described by Huddleston and Pullum (2002: 168-171) also include a group of verbs expressing intellectual states. They call this verb class "verbs of cognition, emotion, and attitude" (2002: 170). It is a large category of stative verbs in the simple present tense with imperfective meaning, e.g. I believe it's illegal. I suppose it's too late. (Huddleston and Pullum 2002: 170).

In his work dealing with semantics of English verbs, Leech (2004) speaks about verbs of inert cognition where the simple present denotes a mental state. $\mathrm{He}$ also explains that they are inert since they "do not involve conscious effort or intention" (2004: 26). Not only prototypical representatives of cognitive verbs such as believe, guess, think, and suppose are included in this group but also the verbs forget, imagine, know or understand.

As has been pointed out by Fetzer, cognitive verbs focus on "internal (or private) domains of reference, viz. the speaker's psychological disposition to which $\mathrm{s} / \mathrm{he}$ has privileged access. Cognitive verbs are frequently contrasted with public verbs of speaking, and consequently private (or subjective) domains of reference are contrasted with public (or external) domains of reference" (Fetzer 2014: 70).

Cognitive verbs, or mental processes in Halliday's terms (1994), have been regarded as expressions of epistemic modality and (inter)subjective viewpoint (cf. Nuyts 2001; Stein and Wright 1995; Traugott 1989; Traugott 1995). Nuyts claims that

"the mental state predicates systematically express subjectivity. Thus, they typically and predominantly occur in contexts in which the speaker voices personal opinions, very often about topics in the realm of strictly individual experiences or concerns, or also in contexts involving antagonism between the views of speaker and hearer". (Nuyts 2001: 390-391)

He further states that subjectivity is connected with expressing a statement or opinion without having thought about it in advance, which means that it is personal. In other words, "cognitive verbs may indicate that subjectively qualified information is made explicit" (Fetzer 2014: 71).

Cognitive verbs occurring in political interviews do not only express subjectivity but they also have an intersubjective function, which means that they show the hearer how the speaker's standpoint expressed in the proposition should be understood. Moreover, intersubjective perspective signals that a certain piece of information conveyed by the speaker is open for negotiation and that the speaker takes the hearer into account. Intersubjectivity also means that the information 
conveyed is known to interactants. If the speaker uses some markers of intersubjectivity, in our case cognitive verbs, s/he attempts to influence the recipient in that the hearer should take over his/her point of view. At the same time, the speaker's proposition may suggest that his/her standpoint is not categorical but that s/he opens up dialogic space for further alternatives. This is called intersubjective positioning (cf. Defrancq, B. and B. De Clerck 2011; Downing, L.H. and B.N. Perucha 2013).

Intersubjective perspective has also been proposed by Givón (1993) who speaks about so-called perception-cognition-utterance (PCU) verbs whose subject "either perceives or cognizes a state or event, or utters a proposition concerning a state or event. That proposition is then coded in the complement clause. The complement clause thus functions, in a way, as the object of the mental or verbal activity depicted in the main clause" (Givón 1993: 133, emphasis in original). He defines a subgroup of PCU verbs expressing an epistemic attitude. This subgroup includes verbs such as think, believe, suspect, guess, suppose, assume, etc. (1993: 135).

\section{Cognitive verbs used as parentheticals}

The genre of political interview is typically connected with establishing the speaker's identity and position. To achieve this, speakers employ a variety of linguistic means, one of them being cognitive verbs. These verbs in the first person simple present tense such as I think, I believe, I mean, I suppose, etc. may function as parentheticals. A standard definition of parentheticals has been offered by Dehé (2014), who defines a parenthetical as a "linguistic entity which is linearly integrated in another linguistic structure but is unrelated to the surrounding linguistic material in one way or another, i.e. in terms of syntactic structure, semantic meaning and/or intonation" (Dehé 2014: 1). Thus, cognitive verbs functioning as parentheticals has been the focus of this study.

The designation "parentheticals" has been taken over from J. O. Urmson (1952) who calls a category of verbs which do not describe actions "parenthetical verbs". Their semantic role, as Urmson claims, is to guide "the hearer to an appreciation of the matrix statement in its social, logical, or evidential context" (1952: 495). These verbs can be used "parenthetically", which means that "in the first-person simple present tense they can take initial, medial and final position in the clause" (Simon-Vandenbergen 2000: 42).

Pragmatically, cognitive verbs may function, depending on the context, both situational and linguistic, and prosody, as intensifiers or mitigators of the illocutionary force. The reason why they may modify the illocutionary force quite easily is that cognitive verbs with first person subject functioning as parentheticals have a weakened semantic value. This is especially true for I think, which has undergone a process of grammaticalization and pragmaticalization (cf. Aijmer 1997; Kaltenböck 2013; Thompson and Mulac 1991; Traugott 1995). Grammati- 
calization is, simply said, a complex type of language change by which lexical items become grammatical structures integrated into the language's grammatical system. Aijmer (1997: 2) adduces to be going to, a marker of future tense, as an example of this process. She further claims that the process of grammaticalization is connected with "the development of new pragmatic meanings, strengthening of conversational implicatures, etc." (1997: 2).

The term pragmaticalization is nowadays used most frequently in connection with discourse markers and modal particles. However, up to now there has not been a proper definition of what pragmaticalization is. Aijmer maintains that pragmaticalized items, such as discourse or pragmatic markers, are those which "involve the speaker's attitude to the hearer" (1997: 2). She treats grammaticalization and pragmaticalization as two separate processes. Some other scholars (see e.g. Barth and Couper-Kuhlen 2002; Günthner and Mutz 2004) are of a different opinion and suggest that pragmaticalization should be considered a specific subtype of a broad category of grammaticalization. In some aspects, it is different from typical manifestations of grammaticalization but in some cases they are almost identical and indistinguishable from each other. Thus, it is not necessary to treat pragmaticalization as a distinct process.

In his study on the development of comment clauses, Kaltenböck (2013) focuses on signs of further grammaticalization of I think. He argues that this parenthetical "is changing from a marker of epistemic modality, typically expressing a lack of speaker commitment, to a pragmatic marker with important textual and discourse-organizational functions. In partial compensation for this loss of epistemic function, formal variants such as I'm thinking, I just think are increasingly used as comment clauses with modal meaning" (2013: 287). As regards the textual function, I think operates as a filler allowing the speaker to think about what to say next. Interactional function in connection with "a variety of functions, such as marking boundaries, introducing a different perspective, etc." (Kaltenböck 2013: 301). Therefore, it may be stated that in spoken interaction I think is predominantly used to express attitude or opinion rather than cogitation.

\section{Material and methodology}

To investigate the use and functions of cognitive verbs in the genre of political interview, a corpus of 40 interviews totalling 114,532 words with British and American politicians was examined. The interviews were released between 2003 and 2008. The transcripts of these interviews were downloaded from the archives of various political programmes. The interviews were broadcast on British and American TV stations (CBS, BBC, CNN, NBC, etc.).

The topics discussed mostly depended on the position which the particular politicians held. Thus, current affairs and internal issues in the UK and USA such as elections, economic issues, healthcare, housing problems, integration problems, presidential campaign and elections, international politics, etc. are debated. 
The function of these interviews is not only to inform the public about these issues but also to persuade and influence potential voters and to focus on the selfpresentation of politicians.

In the corpus cognitive verbs in the first-person singular and first-person plural present tense functioning as parentheticals were found as well as their collocations with discourse markers (e.g. and, because, but, so, well). The analysis focuses on the cognitive verbs think, believe, mean, suppose, guess, and assume both in their affirmative and negative forms. After that their pragmatic functions were identified.

\section{Quantitative analysis and corpora comparison}

At the beginning of this section dealing with frequency of cognitive verbs in the corpus of political interviews, I would like to compare the results of this study with those of Prof. Anita Fetzer on a similar topic (Fetzer 2014). In her paper, she examined the collocations, functions and distribution of cognitive verbs in political interviews and speeches in three different corpora, two dialogic corpora and one monologic. The first dialogic corpus $(\mathrm{C} 1)$ consisted of interviews with British politicians recorded in 1990 (29,209 words) and the other corpus (C2) comprised pre-election interviews recorded between 1997 and 2003 (149,503 words). Interviews in my corpus (C3) were recorded between 2003 and 2008 (114,532 words).

From a diachronic perspective, metaphorically said, covering around 15 years, we can see that the occurrence of I think has increased, which again supports the claim that there is a tendency towards its grammaticalization and weakening of its semantic meaning, and also, as Fetzer (2014: 78) correctly points out, towards an ongoing process of conversationalization of institutional discourse.

\begin{tabular}{|l|c|c|c|}
\hline & C1 (1990) & C2 (1997-2003) & C3 (2003-2008) \\
\hline I think/I do think & 24.3 & 29.76 & 30.08 \\
\hline I don't think & 4.45 & 3.41 & 2.71 \\
\hline we think & 2.05 & 0.8 & 0.87 \\
\hline we don't think & 0.34 & 0.07 & 0 \\
\hline I mean & 11.64 & 11.7 & 10.39 \\
\hline I don't mean & 0 & 0 & 0 \\
\hline we mean & 0 & 0 & 0 \\
\hline we don't mean & 0 & 0 & 0 \\
\hline I believe & 3.42 & 5.21 & 0.44 \\
\hline I don't believe & 0.68 & 1.27 & 0.79 \\
\hline we believe & 1.02 & 1.2 & 0 \\
\hline we don't believe & 0 & 0.2 & \\
\hline
\end{tabular}

Table 1. Comparison of the three corpora (normalized frequency per 10,000 words) 
The occurrence of the first-person plural reference we is much lower than the firstperson singular reference $I$ in all examined cognitive verbs, which may be connected with the fact that politicians prefer to refer to themselves rather than to the political party which they belong to. This reflects their need for self-presentation in front of the audience, so they stress their own viewpoint and express subjectivity. They may also sound authoritative but, at the same time, they do not shift responsibility to anyone else. Further, the lower occurrence of first-person plural parentheticals is related to the political function the speakers represent, which is, in many cases, unique, e.g. Prime Minister, President, Foreign Secretary, etc. Apart from reference to the political party, we may refer to the government.

Looking at the frequency of particular cognitive verbs under investigation more closely, we may find out that I think is by far most frequent, which is connected to the above-mentioned claim that its semantic meaning has been weakened. However, Kärkkäinen (2003) refuses to speak about so called "semantic bleaching", i.e. weakening or loss of the original semantic meaning, in connection with the parenthetical I think. Rather, she emphasises the acquiring of new pragmatic functions and strengthening of conversational implicatures (2003: 178).

I mean is much less frequent in comparison to I think. The reason is that it has a more determinate semantic meaning than I think. From a diachronic perspective, its incidence remains the same. Other forms, such I don't mean or we (don't) mean, do not appear in the corpus at all.

As regards $I$ believe, it is much less recurrent than the two afore-mentioned parentheticals. Similarly to I mean, its meaning is more determinate, it conveys speaker's own true beliefs, s/he feels sure of the truth of the stated fact. It has "the more particularized communicative function" (Fetzer 2014: 68). As for the firstperson-plural forms, they are also infrequent.

Other cognitive verbs, which appear in the corpus, are suppose, guess and assume. All of them occur only with first-person-singular self-reference. Their frequency is rather low due to the fact that suppose and assume are more typical of formal contexts (cf. conversationalization of institutional discourse - Fetzer 2014; Fairclough 1995; Kozubíková Šandová 2014). Guess is more typical of informal American English (Kaltenböck 2013).

\begin{tabular}{|l|c|c|}
\hline & absolute frequency & $\begin{array}{c}\text { normalized frequency } \\
\text { (per 10,000 words) }\end{array}$ \\
\hline I suppose & 3 & 0.26 \\
\hline I guess & 4 & 0.35 \\
\hline I assume & 1 & 0.09 \\
\hline
\end{tabular}

Table 2. Other cognitive verbs 


\section{Pragmatic functions of cognitive verbs in the corpus}

From what has been stated so far, it follows that cognitive verbs belong to the linguistic means that may modify the illocutionary force of propositions. Politicians use them strategically to present themselves positively in front of the audience, to influence their opinions and show the listeners that they are close to them. In this way, cognitive verbs, as any other means of speaker involvement, are used either as intensification or attenuation devices, depending on the context, prosodic prominence and communicative function the speaker intends to achieve.

As is apparent from Table 1, the cognitive verb I think is the most frequent in the corpus. In some contexts, it may be used as a booster to show certainty and confidence of the speaker and to express emphasis. This is usually in the initial position when $I$ think is stressed. In other contexts it functions as a hedge and attenuates the illocutionary force of the utterance, as in Example 1 below. The speaker shows uncertainty and hesitation, which is usually the case when it occurs in the medial or final position with falling intonation. It is important to stress that a particular pragmatic function of I think can only be specified in context, both linguistic and situational. Thus, we may also find instances when I think is not stressed in the initial position and therefore, it has a hedging function.

(1) The difference today, the fundamental political difference is less to do with the traditional, Left, Right politics, as it is, because most people know what makes an effective economy today and so on. It is to do with whether countries are open, whether they're tolerant, whether they embrace people of different views and different faiths, or whether they are closed societies, and I think the future, this is not a Western position, I think the future for our world is in countries opening up to the outside world. (T. Blair 2006-12-11)

In (2) and (3), all instances of I think are used in the initial position with phonological prominence on the pronoun. The speakers want to sound more persuasive and confident, to influence the listeners by emphasising their opinions and invite the audience to adopt their perspective.

(2) JON SOPEL: So Britain is too liberal at the moment on these things.

DAVID CAMERON: I think we're not a responsible society enough. Let me give you .... I think the best way I can put it. Take McDonalds, actually, they're quite a responsible company, they do lots of things in the community. Would we be satisfied as individuals and parents if we said to McDonalds look, okay it's fine you give money to charity, never mind what you put in your burgers. (D. Cameron 2008-03-16)

(3) Q: So how the heck can a government ensure such a target is reached? I mean, the private sector decides how much so and so earns if they work in the private sector. How would that target be met? 
Harriet Harman: [...]. I think there's a lot we can do about it. The point about setting a target is you say 'Right, this has been going on long enough. This matters. We care about it. We're going to set a target and sort it out.' (H. Harman 2007-06-15)

In (4) again, the parenthetical I think boosts the proposition and shows speaker involvement. This involvement is further intensified by the direct address of the interviewer, which is the marker of intersubjectivity.

(4) I think it's fair to say, Wolf, that if you look at any big historical change in the world, it has been turbulent and it's been difficult. And there have been times when it looked as if it was not going well or as planned. (C. Rice 200603-26)

In political discourse, cognitive verbs used parenthetically do not occur only with first-person singular but also with first-person-plural reference, as in the following example. Here the politician does not speak on behalf of himself as an individual but on behalf of his political party:

(5) DAVID MILIBAND: [...] Gordon Brown, as Labour Prime Minister and as British Prime Minister, is setting out very clearly that the Labour Party is a Unionist Party, we believe in the Union. We think Scotland and England and Wales and Northern Ireland are stronger for being together, rather than apart and I think that's the right explanation. (D. Miliband 2008-05-11)

The parenthetical I don't think hedges the proposition over which it has scope. It expresses negative politeness and may be considered as a face-saving strategy of the speaker. In the example below, the speaker does not want to lose face in front of their potential voters.

(6) JON SOPEL: Well how do you make white teenagers, brown teenagers, black teenagers, all feel that they are part of the same society. I mean we saw the shop keeper in that report there, talking about how ultimately, he wanted to remain Pakistani.

RUTH KELLY: I don't think this is really an either or choice. I don't think this is to say that you can't be a part of Britain, without somehow alienating yourself or distancing yourself from your faith or your culture or even the country that you come from. (R. Kelly 2007-06-10)

As already mentioned, in spoken interaction $I$ think expresses rather the attitude of the speaker to the proposition than just cognition. It has undergone the process of grammaticalization and taken over discourse-organizational functions. The cognitive verb I mean shows a similar pattern but its distribution is more restricted than that of $I$ think because its semantic meaning is more determinate. 
"I mean encodes a particular cognitive disposition of the speaker referring to his/ her recontextualized opinion or belief, which may entail his/her intention to utter that particular opinion or belief" (Fetzer 2014: 68).

In Example 7, I mean is used medially with no prosodic prominence so it hedges the proposition. The speaker expresses assumption.

(7) Q: So do you think, with those two who have been most explicit about this, Hazel Blears and Alan Johnson, they are too influenced by, or too worried by, the Conservatives and Cameron and that's just the wrong approach to the way policy-making should develop over the next few years?

Harriet Harman: Yes I do. And I also think it's not my interpretation of how we won in 1997, because if you look back, I mean now the Conservatives agree with the national minimum wage, but they didn't then. They were controversial policies, and I remember the Confederation for British Industry organising lynch mobs for me when I was Shadow Employment Secretary arguing for a minimum wage, and the Conservative sections of the press were howling against us. (H. Harman 2007-06-15)

In the interview, whose extract is cited below, the interviewee suggests improvements in various areas of everyday life of British citizens as proposed by Labour party. She introduces their new policy. While discussing unequal pay conditions, Harriet Harman uses the parenthetical I mean to stress her point and introduce her argument with a stronger pragmatic force.

(8) H. Harman: Well I do think we've got to move forward on this. I mean the Equal Pay Act came into effect in 1975 and here we are in 2007 and the pay gap between men and women is such that women only earn two thirds of what men do. Now, nobody thinks any more that women are less committed to their jobs, they're less hardworking or they're less clever than men, and yet still they only earn two thirds. So I think that we've got to set a target to end unequal pay. (H. Harman 2007-06-15)

Another cognitive verb occurring in the corpus but with not so high frequency, as the other two cognitive verbs described above, is I believe. Similarly to I mean, it has a more specific semantic meaning than I think. When using the parenthetical I believe, the speaker feels sure of the truth of the proposition. It is "the most straight-forward construction of the three because of its determinate meaning" (Fetzer 2014: 68). Pragmatically, it is mostly classified as a booster. However, as Fetzer points out, I believe, similarly to $I$ think, is a polysemous verb, in other words, it may have both a boosting and hedging function. "The latter is interdependent on its medial or final position and on co-occurrence with other attenuating devices" (Fetzer 2014: 91), as in (9):

(9) RICE: Well, Abu Mazen is, of course, the head of the PLO -- the chairman 
of the PLO. And he is the president of all Palestinians. And it is actually his mandate to negotiate. Now, the people in that room, more or less, discussed, I believe, to have a two-state solution and accept a two-state solution. Hamas does not accept a two-state solution. It doesn't even accept the right of Israel to exist. How can you negotiate when you don't even accept the right of the other party to exist? How can you negotiate when you will not renounce violence as a way forward? (C. Rice 2007-11-28)

The negated form I don't believe functions as a hedge attenuating the part of the utterance over which it has a scope:

(10) HAZEL BLEARS: It's really important that I help to make sure that we use whatever election happens as an opportunity to bring the Party together and to have a debate around policy, as Kevin Barron was saying, you shouldn't be afraid of that. I don't believe there's an ideological split in the Party at all. But there are new challenges for which we will need new ideas and Party members, you know, we're a democratic party, Party members should have a say in formulating those policies as well, together with colleagues in the trade unions. And that's going to be me my absolute top priority. (H. Blears 2006-09-17)

\section{Co-occurrence of cognitive verbs with discourse markers}

Cognitive verbs frequently co-occur with various discourse markers, that is why this issue has also been dealt with briefly in this paper.

\begin{tabular}{|l|c|c|}
\hline & AF & NF per $\mathbf{1 0 , 0 0 0}$ words \\
\hline and I think & 88 & 7.68 \\
\hline and I don't think & 8 & 0.70 \\
\hline but I think & 34 & 2.97 \\
\hline but I don't think & 5 & 0.44 \\
\hline because I don't think & 2 & 0.17 \\
\hline so I think & 12 & 1.05 \\
\hline so I don't think & 2 & 0.17 \\
\hline well I think & 11 & 0.96 \\
\hline yes I think & 4 & 0.35 \\
\hline then I think & 5 & 0.44 \\
\hline now I think & 9 & 0.79 \\
\hline no I think & 6 & 0.52 \\
\hline so no I think & 1 & 0.09 \\
\hline no I don't think & 4 & 0.35 \\
\hline and so I think & 4 & 0.35 \\
\hline
\end{tabular}

Table 3. Discourse markers with $I$ think 


\begin{tabular}{|l|c|c|}
\hline & AF & NF per 10,000 words \\
\hline and I believe & 8 & 0.70 \\
\hline but I believe & 6 & 0.52 \\
\hline but I don't believe & 3 & 0.26 \\
\hline well I believe & 2 & 0.17 \\
\hline because I believe & 3 & 0.26 \\
\hline no I don't believe & 1 & 0.09 \\
\hline
\end{tabular}

Table 4. Discourse markers with I believe

\begin{tabular}{|l|c|c|}
\hline & AF & NF per 10,000 words \\
\hline and I mean & 3 & 0.26 \\
\hline but I mean & 5 & 0.44 \\
\hline because I mean & 1 & 0.09 \\
\hline well I mean & 7 & 0.61 \\
\hline now I mean & 1 & 0.09 \\
\hline no I mean & 2 & 0.17 \\
\hline
\end{tabular}

Table 5. Discourse markers with I mean

As is apparent from the tables above, the most frequent configurations of cognitive verbs with discourse markers in the corpus are those with $I$ think, the least frequent with I mean. This is in accordance with the claim above that $I$ think has lost its semantic meaning and is also structurally and functionally more flexible, whereas I mean is semantically more determined and its configurational ability is not so strong. Therefore, the incidence of I mean with discourse markers is not so recurrent. Regarding the negated forms of the cognitive verbs under examination, they are not so frequent in co-occurrences with discourse markers.

The discourse markers and, but, well and no were found in configurations with all these three verbs. The most frequent collocation of $I$ think and I believe is with the discourse marker and, while the most frequent collocation of I mean is with the discourse marker well. Overall, the most frequent co-occurrences of cognitive verbs with discourse markers are and I think, but I think, and so I think.

Correspondingly to the parenthetical I think, the discourse marker and also performs many pragmatic functions, such as expressing continuation, coordination of ideas, additive relation, etc. (cf. Schiffrin 1987), depending on the context. In connection with $I$ think, the discourse marker and further boosts the argument introduced by this parenthetical.

(11) Harriet Harman: Well I think there is. But I think ... my view of the task for us is that we need to understand what the challenges are that face Britain. We need to listen to and understand the problems that there are 
in people's lives and we need to have policies to address those and if the policies need to be bold then we should be radical in bringing forward those policies. And I think it would be wrong, when we're in government and have got the responsibility to take the country forward to be allowing the Conservatives to dictate our position. (H. Harman 2007-0615)

In (11), and I think is used in the initial position with a prosodic prominence. It is surrounded by other configurations with discourse markers such as well I think and but I think expressing subjectification, which is further marked by employing the expression my view...is. Also, intensification by repetition of the verb need to is utilized, which speaks for the fact that and I think intensifies the illocutionary force of the utterance.

Since it is very frequent in political discourse, Fetzer (2014: 79-80) assigns the cluster and I think the status of "a salient discourse pattern in the context of spoken political discourse." When it connects two arguments, indicating that the second argument supports the first one, this second argument is stronger that the first. In such a case, I think is a booster and intensifies "the discourse-connecting function of the pragmatic marker and with epistemic certainty and with the speaker's commitment towards the validity of his/her claim" (2014: 80). Thus, and I think is a marker of intersubjectivity and shows the recipient how to interpret the message.

The configurations of I think with other discourse markers are very low in frequency, that is why they cannot be assigned the status of a salient discourse pattern. Rather, they are assigned "the function of a pragmatic marker coloured by subjectification" (Fetzer 2014: 80).

In the example below, yes works as a cohesive device connecting two arguments. It indicates the speaker's agreement with them and strengthens the argument expressed in the proposition. Also, the immediate linguistic context supports the boosting function of this cluster.

Q: Will the government get a majority on it.

ALAN JOHNSON: Yes, I think we will. I, I, I'm absolutely certain that we will. I think once we've talked all this through and once we've I mean you only have to look at the seven planes that were due to be blown up over the Atlantic, to see, as Jacqui Smith has said today, this is a very serious problem. (A. Johnson 2008-04-13)

Since the incidence of the configuration and I believe is high in political interviews, it also has the status of a salient discourse pattern. The semantic meaning of I believe is more determinate than that of I think, also in this configuration, therefore it functions only as a booster showing a high degree of speaker involvement with the proposition, as in Example 13. 
Q: Are we completely secure?

BUSH: The answer's no, but we're working to get there. And can we ever be? I hope so. Because our most important job is to protect the people. And I - I believe the best way to do it, by the way, is not only secure the homeland and give our people the tools necessary to do so, but is to stay on the offense against these people and to bring them to justice before they come here to hurt us. And that's what we're doing. (G.W. Bush 2006-09-06)

Intersubjective function manifests itself in configurations of $I$ believe with argumentative discourse markers such as because, but, (and) yes, and now. The speaker shows his recipients how his claims should be understood. In (14) below, the speaker uses the cluster because I believe to intensify the strength of his argument and to show that his standpoint is unequivocal.

(14) McCAIN: I do. I do because they're our sons and daughters and all of us are committed to them and proud of the best, the very best of America. I think what Fred was saying there was that if the American people no longer support an enterprise in which our military is engaged, then it's a matter of time before we have to withdraw. And that's why this coming debate in the middle of September is so important, because I believe those of us who believe that we are succeeding have to convince the American people of it. (J. McCain 2007-08-16)

As regards the configurations with $I$ mean, they are again not so frequent as the collocations with I think. I mean, similarly to I believe, is more semantically determinate and its meaning has not been weakened so much. That it why its collocation patterns are not so varied. The most frequent structure is well I mean, followed by but I mean. Both well and but express contrasting attitude to a proposition. The speaker shows his different point of view and emphasises it by using this configuration:

(15) TONY BLAIR: No, I'm not saying that, but I mean you know, it's hardly surprising isn't it, it's not... shock horror headline, someone in the Labour Party doesn't agree with Neo-Cons. (T. Blair 2007-01-28)

\section{Conclusions}

This study investigated the use, distribution and functions of cognitive verbs in political interviews. More specifically, the focus was on the most frequent verbs in the corpus, namely think, mean, and believe occurring the first-person singular and first-person plural present tense. These verbs function parenthetically, which means that they are functionally and structurally flexible and independent of the 
complement clause and they are not followed by the complementizer that.

Parenthetically-used cognitive verbs in political interviews may either intensify or attenuate the illocutionary force of the utterance, depending on the linguistic and situational context, on the syntactic position and prosody. If used initially with phonological prominence, they function as boosters, if used medially or finally without phonological prominence, they tend to hedge the proposition. When determining pragmatic functions of these parentheticals, prosody alone may not necessarily reveal them. Both the situational and linguistic context is relevant. Lexical items may be unstressed because of their position or because being repeated in the discourse, not necessarily because of their function. They may be stressed not because of their importance or contribution to the propositional meaning, but because of the rhythmic structure of the sentence.

The examined cognitive verbs express subjectivity, which indicates that politicians focus on self-presentation and expressing their attitudes and opinions as correct ones, they also invite the recipients to adopt the politician's perspective. In this way, cognitive verbs may be regarded as markers of intersubjectivity.

I think is the prototypical representative of cognitive verbs and accordingly the most frequent in my corpus. Compared to the incidence of I think, the distribution of I mean and I believe is not that high. The reason is that the other two parentheticals have a more determinate semantic meaning than I think. Also, they have not undergone the process of grammaticalization and pragmaticalization as I think has. I think, therefore, does not express cognition only but rather speaker attitude to the proposition. It also has interactional function. The distribution of $I$ mean is more restricted compared to that of $I$ think. It is due to its more precise semantic meaning. According to Fetzer, I mean is present primarily "in negotiationof-meaning sequences", it "brackets units of talk, and functions as reformulation, if not self-repair. It may also be used to introduce an argument with a stronger pragmatic force" or make an explanation or correction of a statement (2014: 68). I believe is also a cognitive verb with rather specific and more determinate semantic meaning. Thus, its frequency of occurrence in the corpus is low compared to I think and I mean. When using I believe the speaker feels sure of the truth of the information conveyed. It is considered as "the most straight-forward" and "the least grammaticalized [construction]" of the three cognitive verbs examined because of its determinate meaning (Fetzer 2014: 68). Other cognitive verbs appearing in the interviews, assume, suppose, and guess, are low in frequency because their use is constrained to more formal contexts, or, in case of guess to informal language.

Another aim of this paper was to examine co-occurrence of cognitive verbs with discourse markers. I think collocates with a number of discourse markers, e.g. and, but, so, well, yes, and no. As the configuration and I think occurs frequently in political discourse, Fetzer (2014: 79-80) assigns it the status of "a salient discourse pattern in the context of spoken political discourse." "And I think fulfills an important intersubjective function in argumentative discourse, instructing the addressee(s) how the speaker intends them to interpret a particular piece 
of discourse (or that it is open for negotiation)" (Fetzer 2008: 251). Other collocations of I think with discourse markers do not occur so frequently, therefore, they cannot be assigned the status of a salient discourse pattern. The cluster and I believe is also frequent in political discourse, so it has also been ascribed the status of a salient discourse pattern. It indicates that

"the argument to follow is a firm backing of the previous one. Because of its more determinate semantics I believe has retained almost its full semantic potential in that particular configuration, and can therefore only function as a booster, intensifying the discourse-connecting function of the pragmatic marker with the speaker's firm commitment towards the validity of her/his contribution" (Fetzer 2014: 81).

The collocation of I mean with the discourse marker and is very low (a mere three occurrences in the corpus), which again derives from its restricted semantics.

\section{References}

Aijmer, Karin (1997) "I think - an English Modal Particle.” In: Swan, Toril and Olaf J. Westvik (eds.) Modality in Germanic Languages. Historical and Comparative Perspectives. Berlin: Mouton, 1-47.

Barth, Dagmar and Elizabeth Couper-Kuhlen (2002) "On the development of final though: A case of grammaticalization?" In: Wischer, Ilse and Gabriele Diewald (eds.) New Reflections on Grammaticalization (Typological Studies in Language 49). Amsterdam and Philadelphia: John Benjamins, 345-361.

Biber, Douglas (1988) Variation across Speech and Writing. Cambridge: Cambridge University Press.

Defrancq, Bart and Bernard De Clerck (2011) "Intersubjective Positioning in French and English. A Contrastive Analysis of 'ca dépend' and 'it depends'." In: Aijmer, Karin (ed.) Contrastive Pragmatics. Amsterdam and Philadelphia: John Benjamins, 40-71.

Dehé, Nicole (2014) Parentheticals in Spoken English. The Syntax-Prosody Relation. Cambridge: Cambridge University Press.

Downing, Laura Hidalgo and Begona N. Perucha (2013) "Modality and Personal Pronouns as Indexical Markers of Stance: Intersubjective Positioning and Construction of Public Identity in Media Interviews." In: Marín-Arrese, Juana I., Marta Carretero, Jorge Arús Hita and Johan van der Auwer (eds.) English Modality: Core, Periphery and Evidentiality. Berlin and New York: Mouton de Gruyter, 379-410.

Fairclough, Norman (1995) Media Discourse. London: Edward Arnold.

Fetzer, Anita (2008) "And I Think That Is a Very Straightforward Way of Dealing With It": The Communicative Function of Cognitive Verbs in Political Discourse." Journal of Language and Social Psychology 27 (4): 384-396.

Fetzer, Anita (2014) "I think, I mean and I believe in Political Discourse. Collocates, Functions and Distribution." Functions of Language 21 (1): 67-94.

Givón, Thomas (1993) English Grammar. A Function-Based Introduction. Amsterdam and Philadelphia: John Benjamins.

Günthner, Susanne and Katrin Mutz (2004) "Grammaticalization vs. pragmaticalization? The development of pragmatic markers in German and Italian." In: Bisang, Walter, Nikolaus P. Him- 
melmann and Björn Wiemer (eds.) What makes Grammaticalization? A look from its fringes and its components (Trends in Linguistics: Studies and Monographs 158). Berlin and New York: Mouton de Gruyter, 77-107.

Halliday, Michael Alexander Kirkwood (1994) Introduction to English Functional Grammar. London: Arnold.

Huddleston, Rodney and Geoffrey K. Pullum (2002) The Cambridge Grammar of the English Language. Cambridge: Cambridge University Press.

Kaltenböck, Gunther (2013) "The Development of Comment Clauses." In: Aarts, Bas (ed.) The Verb Phrase in English. Investigating Recent Language Change with Corpora. Cambridge: Cambridge University Press, 286-317.

Kärkkäinen, Elise (2003) Epistemic Stance in English Conversation: A Description of its Interactional Functions, with a Focus on I think. Amsterdam: Benjamins.

Kozubíková Šandová, Jana (2014) Speaker Involvement in Political Interviews. Frankfurt am Main: Peter Lang.

Leech, Geoffrey (2004) Meaning and the English Verb. $3^{\text {rd }}$ edition. London and New York: Routledge.

Nuyts, Jan (2001) "Subjectivity as an Evidential Dimension of Epistemic Modal Expressions." Journal of Pragmatics 33 (3): 383-400.

Palmer, Frank Robert (1987) The English Verb. $2^{\text {nd }}$ edition. London: Longman.

Quirk, Randolph, Greenbaum Sidney, Leech Geoffrey, Svartvik Jan (1985) A Comprehensive Grammar of the English Language. London: Longman.

Schiffrin, Deborah (1987) Discourse Markers. Cambridge: Cambridge University Press.

Simon-Vandenbergen, Anne-Marie (2000) “The Functions of I Think in Political Discourse." International Journal of Applied Linguistics 10 (1): 41-63.

Stein, Dieter and Susan Wright (eds.) (1995) Subjectivity and Subjectivisation: Linguistic Perspectives. Cambridge: Cambridge University Press.

Thompson, Sandra A. and Anthony Mulac (1991) "A Quantitative Perspective on the Grammaticalization of Epistemic Parentheticals in English." In: Traugott, Elizabeth and Bernd Heine (eds.) Approaches to Grammaticalization, Vol. 2. Amsterdam and Philadelphia: John Benjamins, 313-339.

Traugott, Elizabeth (1989) "On the Rise of Epistemic Meanings in English: An Example of Subjectification in Semantic Change." Language 65 (1): 31-55.

Traugott, Elizabeth (1995) "Subjectification in Grammaticalization." In: Stein, Dieter and Susan Wright (eds.) Subjectivity and Subjectivisation: Linguistic Perspectives. Cambridge: Cambridge University Press, 31-54.

Urmson, James Opie (1952) "Parenthetical Verbs.” Mind 61 (244): 480-496.

\section{Sources}

Blair, Tony (2003a) Transcript of Blair's Iraq interview. 6 February, 2003. BBC NEWS. http:// news.bbc.co.uk/2/hi/programmes/newsnight/2732979.stm.

Blair, Tony (2003b) Tony Blair Interview - BBC Newsnight. 29 April, 2003. BBC NEWS. http:// news.bbc.co.uk/2/hi/events/newsnight/1372220.stm.

Blair, Tony (2006a) Blair/Frost Iraq 'Disaster' Interview: The Full Transcript. 11 December, 2006. Al-Jazeera English. http://english.aljazeera.net/programmes/frostoverthewor 1d/2006/11/2008525184756477907.html.

Blair, Tony (2006b) Tony Blair Interview: Complete Transcript George Stephanopoulos' Exclusive Interview with British Prime Minister. 10 December, 2006. ABC NEWS. http://abcnews.go.com/ ThisWeek/Politics/ Story?id=2720220\&page=1.

Blair, Tony (2007a) Blair: 'I'm going to finish what I started.' 28 January, 2007. BBC NEWS. http:// news.bbc.co.uk/2/hi/programmes/politics show/ 6293605.stm. 
Blair, Tony (2007b) Blair Defends his 10-year Legacy. 15 April, 2007. BBC NEWS. http://news. bbc.co.uk/1/low/programmes/politicsc_show/6544295.stm.

Blears, Hazel (2006) Interview with Hazel Blears, Chair of the Labour Party. 17 September, 2006. BBC NEWS. http://news.bbc.co.uk/1/low/programmes/ politics_show/5354132.stm.

Blears, Hazel (2007) Hazel Blears Interview. 25 February, 2007. BBC NEWS. http://news.bbc. co.uk/1/low/programmes/politics_show/6381575.stm.

Bush, George W. (2006a) President Bush Sits Down with Bob Schieffer. 27 January, 2006. CBS NEWS. http://www.cbsnews.com/stories/2006/01/27/ eveningnews/main1248952 page4.shtml.

Bush, George W. (2006b) Couric's Interview with President Bush. 6 September, 2009. CBS NEWS. http://www.cbsnews.com/stories/2006/09/06/five years/main1979933 page4.shtml, http:// www.cbsnews.com/stories/2006/09/06/ five years/main1980074_page4.shtml.

Bush, George W. (2007a) President Spoke to 60 Minutes' Scott Pelley at Camp David. 14 January, 2007. CBS NEWS. http://www.cbsnews.com/stories/2007/01/14/60minutes/main2359119 page5.shtml.

Bush, George W. (2007b) President Bush Defends Decision to Send Additional Troops to Iraq. 16 January, 2007. PBS Newshour. http://www.pbs.org/ newshour/bb/white_house/jan-june07/ bush 01-16.html.

Bush, George W. (2007c) NPR Interview with President George W. Bush. 29 January, 2007. NPR. http://www.npr.org/templates/story/story.php?storyId $=7065633$.

Bush, George W. (2008) George W. Bush BBC Interview. 14 February, 2008. BBC NEWS. http:// news.bbc.co.uk/2/hi/americas/7245670.stm.

Cameron, David (2008) David Cameron Interview. 16 March, 2008. BBC NEWS. http://news.bbc. co.uk/2/low/programmes/politics_show/7286279.stm.

Clinton, Hillary (2006) Hillary Clinton Talks with Nightline's Cynthia McFadden. 7 September, 2006. ABC NEWS. http://abcnews.go.com/Nightline/ story?id=2403942.

Clinton, Hillary (2007) Hillary Clinton Interview. 11 October, 2007. CNBC. http://www.cnbc.com/ $\mathrm{id} / 21254463 /$.

Clinton, Hillary (2008) Hillary Clinton Interview. Meet the Press. 13 January, 2008. MSNBC. http://www.msnbc.msn.com/id/22634967/page/6/.

Cooper, Yvette (2007) Yvette Cooper Interview. 15 July, 2007. BBC NEWS. http://news.bbc. co.uk/1/low/programmes/politics_show/6270720.stm.

Duncan, Alan (2006) Jon Sopel interviewed Alan Duncan MP. 2 July, 2006. BBC NEWS. http:// news.bbc.co.uk/2/hi/programmes/politics_show/5124232.stm.

Gove, Michael (2008a) Interview with Michael Gove MP. 2 March, 2008. BBC NEWS. http:// news.bbc.co.uk/2/low/programmes/politics_show/7261388.stm.

Gove, Michael (2008b) On the Politics Show, Jon Sopel Interviewed Michael Gove, MP. 29 April, 2008. BBC NEWS. http://news.bbc.co.uk/2/low/programmes/ politics_show/7372603.stm.

Hague, William (2008) Hague on Zimbabwe Recount. 27 April, 2008. BBC NEWS. http://news. bbc.co.uk/2/low/programmes/politics_show/7362715.stm.

Harman, Harriet (2007a) Harriet Harman Interview. 15 June, 2007. www.harrietharman.org.

Harman, Harriet (2007b) Harman: 'Increase in spending...' 17 June, 2007. BBC NEWS. http:// news.bbc.co.uk/1/low/programmes/politics show/6746407.stm.

Harman, Harriet (2008) Harriet Harman Interview. 29 April, 2008. BBC NEWS. http://news.bbc. co.uk/2/low/programmes/politics_show/7372602.stm.

Johnson, Alan (2008) On the Politics Show, Jon Sopel interviewed Alan Johnson MP, Secretary of State for Health. 13 April, 2008. BBC NEWS. http://news.bbc.co.uk/2/low/programmes/politics_show/7336215.stm.

Kelly, Ruth (2007) Interview with Ruth Kelly, MP, Secretary of State for Communities \& Local Government. 10 June, 2007. BBC NEWS. http://news.bbc.co.uk/1/low/programmes/politics_ show/6725673.stm. 
May, Teresa (2008) On the Politics Show, Jon Sopel Interviewed Shadow Leader, House of Commons, Theresa May. 9 March, 2008. BBC NEWS. http://news.bbc.co.uk/2/low/programmes/ politics_show/7276464.stm.

McCain, John (2007) Larry King Live: Interview with Senator John McCain. 16 August, 2007. CNN.com. http://transcripts.cnn.com/TRANSCRIPTS/0708/16/lk1.01.html.

Miliband, David (2008) David Miliband Interview. 11 May, 2008. BBC NEWS. http://news.bbc. co.uk/2/low/programmes/politics_show/7385768.stm.

Napolitano, Janet (2008) Interview with Arizona Governor Janet Napolitano. 24 April, 2008. FOX NEWS. http://www.foxnews.com/story/0,2933,595926,00.html.

Palin, Sarah (2008) '20/20' Co-Anchor Elizabeth Vargas Speaks with Alaska Governor on Campaign Trail. 29 October, 2008. ABC NEWS. http://abcnews.go.com/Politics/Vote2008/ Story?id $=6140030$ \&page $=2$.

Rice, Condoleezza (2006) CNN Late Edition with Wolf Blitzer: Interview With Condoleezza Rice. 26 March, 2006. CNN.com. http://transcripts.cnn.com/ TRANSCRIPTS/0603/26/le.01.html.

Rice, Condoleezza (2007a) Interview on NBC's Today Show with Matt Lauer: Condoleezza Rice. 19 March, 2007. NBC. http://www.state.gov/secretary/rm/2007/ mar/81865.htm.

Rice, Condoleezza (2007b) CNN Late Edition with Wolf Blitzer: Interview With Condoleezza Rice. 29 April, 2007. CNN.com. http://transcripts.cnn.com/TRANSCRIPTS/ 0704/29/le.01.html.

Rice, Condoleezza (2007c) Interview on the Charlie Rose Show: Secretary Condoleezza Rice. 7 May, 2007. U.S. Department of State. http://www.state.gov/secretary/ rm/2007/may/84460.htm.

Rice, Condoleezza (2007d) Cynthia's McFadden's Interview with Condoleezza Rice. 28 November, 2007. ABC News. http://abcnews.go.com/Nightline/Story?id =3927548\&page=1.

Rice, Condoleezza (2008) Interview with the Washington Times Editorial Board: Secretary Condoleezza Rice, 27 March, 2008. U.S. Department of State. http://www.state.gov/secretary/ $\mathrm{rm} / 2008 / 03 / 102757 . \mathrm{htm}$.

Smith, Jackie (2005) Interview with Jacqui Smith. 27 November, 2005. BBC NEWS. http://news. bbc.co.uk/1/low/programmes/politics_show/4475810.stm.

Jana Kozubíková ŠAndová is Assistant Professor of English Linguistics at the University of South Bohemia in České Budějovice, Czech Republic. Her research interests include topics on the interface between pragmatics and semantics, e.g. pragmatic functions of linguistic means in political interviews, intersubjective positioning in political and scientific discourse. Her latest publications deal with pragmatic aspects of political discourse.

Address: Mgr. Jana Kozubíková Šandová, Ph.D., Department of English, Faculty of Education, University of South Bohemia, Jeronýmova 10, 37115 České Budějovice, Czech Republic. [e-mail: sandova@pf.jcu.cz] 
